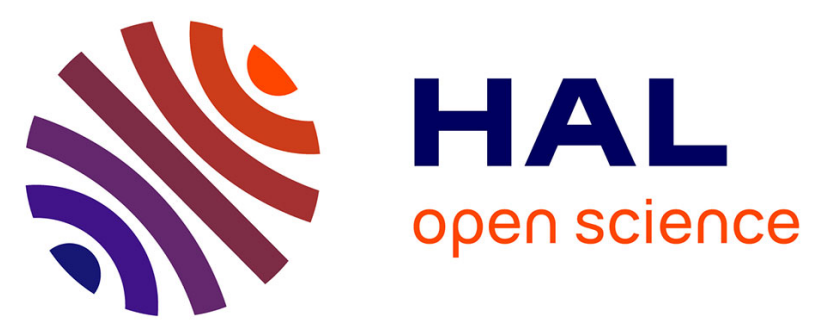

\title{
Negligible degradation upon in situ voltage cycling of a PEMFC using an electrospun niobium-doped tin oxide supported Pt cathode
}

Iuliia Savych, Surya Subianto, Yannick Nabil, Sara Cavaliere, Deborah Jones, Jacques Rozière

\section{To cite this version:}

Iuliia Savych, Surya Subianto, Yannick Nabil, Sara Cavaliere, Deborah Jones, et al.. Negligible degradation upon in situ voltage cycling of a PEMFC using an electrospun niobium-doped tin oxide supported Pt cathode . Physical Chemistry Chemical Physics, 2015, 17, pp.16970-16976. 10.1039/C5CP01542A . hal-01168909

\section{HAL Id: hal-01168909 \\ https://hal.science/hal-01168909}

Submitted on 29 Jun 2015

HAL is a multi-disciplinary open access archive for the deposit and dissemination of scientific research documents, whether they are published or not. The documents may come from teaching and research institutions in France or abroad, or from public or private research centers.
L'archive ouverte pluridisciplinaire HAL, est destinée au dépôt et à la diffusion de documents scientifiques de niveau recherche, publiés ou non, émanant des établissements d'enseignement et de recherche français ou étrangers, des laboratoires publics ou privés. 


\title{
Negligible degradation on in situ voltage cycling of a PEMFC with electrospun niobium-doped tin oxide supported Pt cathode
}

\author{
Iuliia Savych, ${ }^{a}$ Surya Subianto, ${ }^{a}$ Yannick Nabil, ${ }^{a}$ Sara Cavaliere, ${ }^{a, *}$ Deborah Jones, ${ }^{a}$ Jacques Rozière ${ }^{a}$
}

\begin{abstract}
Novel platinum-catalysed corrosion-resistant loose-tube-structured electrocatalysts for proton exchange membrane fuel cells have been obtained using single-needle electrospinning associated with a microwave-assisted polyol method. Monodisperse platinum particles supported on $\mathrm{Nb}-\mathrm{SnO}_{2}$ demonstrated higher electrochemical stability than conventional Pt/C electrodes during ex situ potential cycling and comparable activity in the oxygen reduction reaction. In situ fuel cell operation under accelerated stress test conditions of a membrane electrode assembly elaborated with a $\mathrm{Pt} / \mathrm{C}$ anode and $\mathrm{Pt} / \mathrm{Nb}-\mathrm{SnO}_{2}$ cathode confirmed that voltage loss is significantly lower with the novel cathode than with an MEA prepared with conventional Pt/C supported electrocatalysts. Furthermore, the $\mathrm{Nb}-\mathrm{SnO}_{2}$ stabilized the supported platinum nanoparticles against dissolution, migration and reprecipitation in the membrane. $\mathrm{Pt} / \mathrm{Nb}-\mathrm{SnO}_{2}$ loose-tubes constitute a mitigation strategy to two known degradation mechanisms in PEMFC: corrosion of the carbon support at the cathode, and dissolution of $\mathrm{Pt}$ at high cell voltages.
\end{abstract}

\section{Introduction}

Fuel cell electrocatalyst support materials are required to have high electronic conductivity, specific surface area, electrochemical and chemical stability under operating conditions and the ability to form a layer with the required porous structure to allow reactant gas ingress and product water egress. Carbon blacks have been successful at providing these properties, with the notable exception of electrochemical stability at high potentials. High potentials can arise at both anode and cathode during fuel cell operation, for example under stop/start conditions.

Whilst some mitigation strategies within the MEA are possible, such as using catalyst that doesn't promote ORR on the anode, carbon corrosion is not prevented in this way, only reduced. Transition metal oxides ${ }^{1}$ are more stable under cell reversal and start/stop conditions which explains the current high interest in the development of synthesis approaches leading to transition metal oxides of high surface area and relatively high electronic conductivity such as $\mathrm{TiO}_{2}{ }^{2-4}, \mathrm{WO}_{2}{ }^{5-7}, \mathrm{SnO}_{2}{ }^{8-11}$. A recent study on the platinum aggregation and redispersion on a range of metal oxide surfaces under the operating conditions of PEMFC cathodes showed that $\mathrm{NbO}_{2}$ and $\mathrm{SnO}_{2}$ are good redispersion supports ${ }^{12}$. They could, furthermore, play a co-catalyst role and promote the electrocatalytic reaction as a result of a strong metalsupport interaction (SMSI) ${ }^{13}$. Doping tin oxide with aliovalent ions ( $\mathrm{Sb}, \mathrm{Nb}$, Ta and $\mathrm{Ru}$ etc.) is an effective approach ${ }^{14-18}$ to increasing its electronic conductivity to that required for efficient electron transfer at the electrode. Several recent ex situ studies into the use of doped tin oxide as electrocatalyst support for cathode of proton exchange membrane fuel cells have concluded that $\mathrm{Pt}$ supported on $\mathrm{Nb} / \mathrm{SnO}_{2}, \quad \mathrm{Sb} / \mathrm{SnO}_{2}$ and $\mathrm{Ru} / \mathrm{SnO}_{2}$ demonstrates good activity for oxygen reduction reaction $(\mathrm{ORR})^{8,9,16,17,19,20}$ and greater stability on cycling to high cell voltage than $\mathrm{Pt} / \mathrm{C}$ electrocatalysts.

One-dimensional structures such as nanofibres and nanotubes have demonstrated unique electrical properties and high specific surface area ${ }^{21}$. Pt supported on $\mathrm{SnO}_{2}$ nanowires directly grown on carbon-paper fuel cell backings exhibited higher activity for ORR than a standard Pt/C electrode ${ }^{11}$. An efficient technique to prepare 1D nanomaterials with controlled diameters and structures is electrospinning and interest in electrospun ceramic fibres for energy conversion devices has grown dramatically in recent years ${ }^{22}$. While several studies have described the preparation of electrospun $\mathrm{TiO}_{2}$ fibres for application in PEMFC cathodes ${ }^{2,23-27}$, investigation of $\mathrm{Pt}$ loaded $\mathrm{SnO}_{2}$ fibres prepared by electrospinning revealed unique electrocatalytic activity for the hydrogen oxidation reaction while inhibiting the ORR, and are potentially used in the anode side 28,29 .

In recent work we described the elaboration and formation mechanism of an unusual fibre-in-tube ("loose-tube") architectured $\mathrm{Nb}$ doped tin oxide obtained by electrospinning ${ }^{30}$. The doping drove the morphology to hollow fibres and also increased the electrical conductivity to $210^{-2} \mathrm{~S} \mathrm{~cm}^{-1}$ at RT, a value that is in the range of other recently reported doped $\mathrm{SnO}_{2}$ nanomaterials ${ }^{16,18,31}$. Preliminary results have shown high electrochemical stability upon voltage cycling of the catalysed supports. In this work, we investigated the ORR activity and the 
stability over time of $\mathrm{Pt}$ electrocatalysts supported on $\mathrm{Nb}$ doped $\mathrm{SnO}_{2}$ loose-tubes in both ex situ and in situ fuel cell measurements. We reveal from combined electrochemical and electron microscopic characterisation that migration of platinum from the cathode and reprecipitation in the membrane during fuel cell operation under accelerated ageing conditions is significantly lower with the $\mathrm{Pt} / \mathrm{Nb}-\mathrm{SnO}_{2}$ support at the cathode than with $\mathrm{Pt} / \mathrm{C}$, and conclude that such alternative supports represent a mitigation strategy not only for support corrosion, but also for deleterious loss of catalyst from the cathode to the membrane.

\section{Experimental}

\section{Synthesis of $\mathrm{Pt} / \mathrm{Nb}$ doped $\mathrm{SnO}_{2}$ loose-tubes}

The detailed synthesis of $\mathrm{Pt} / \mathrm{Nb}$-doped $\mathrm{SnO}_{2}$ loose-tubes was reported elsewhere ${ }^{30}$. For the preparation of $\mathrm{Nb}-\mathrm{SnO}_{2}, 0.78 \mathrm{~g}$ of tin(II) chloride (98\%, Sigma-Aldrich) and $0.06 \mathrm{~g}$ of niobium(V) chloride (98\% min., Merck) were dissolved in $5.7 \mathrm{~mL}$ of absolute ethanol (puriss., Sigma-Aldrich) and added to a solution of $0.8 \mathrm{~g}$ of polyvinylpyrrolidone (average $\mathrm{M}_{\mathrm{w}} \sim 1,300,000$, Aldrich) in $3.1 \mathrm{~mL}$ of N,N-dimethylformamide (98 \% min., Fluka). The resulting mixture was stirred at least for $1 \mathrm{~h}$ in order to obtain homogeneous solution. This solution was electrospun at room temperature using an applied voltage of $15 \mathrm{kV}$, a needlecollector distance of $10 \mathrm{~cm}$ and a flow rate of $0.4 \mathrm{~mL} \mathrm{~h}^{-1}$. The asspun fibres were calcined at $600{ }^{\circ} \mathrm{C}$ for $4 \mathrm{~h}$ in air with a heating rate of $5{ }^{\circ} \mathrm{C} \mathrm{min}^{-1}$.

A microwave-assisted polyol method was used to synthesize Pt nanocatalyst particles. $130 \mathrm{mg}$ of hexachloroplatinic acid $\left(\mathrm{H}_{2} \mathrm{PtCl}_{6} 6 \mathrm{H}_{2} \mathrm{O}, 99.9 \%\right.$ Alfa Aesar) were dissolved in $90 \mathrm{~mL}$ of ethylene glycol $(99.5 \%$, Fluka) and the $\mathrm{pH}$ was adjusted to $\mathrm{pH}$ 11.4 using $1 \mathrm{M} \mathrm{NaOH}$ solution (98\%, Sigma Aldrich) in ethylene glycol. The resulting solution was heated at $120^{\circ} \mathrm{C}$ for 6 minutes in a microwave reactor (MiniFlow 200SS Sairem). A suspension containing $112 \mathrm{mg}$ of the $\mathrm{Nb}-\mathrm{SnO}_{2}$ fibres in $5 \mathrm{~mL}$ ethylene glycol was added to the as-synthesized Pt nanoparticle suspension and the $\mathrm{pH}$ was adjusted to 2 . After gentle stirring for 24 hours the product was recovered by filtration, washed with milli-Q water and ethanol and dried at $160{ }^{\circ} \mathrm{C}$ for $1 \mathrm{~h}$.

\section{Physico-chemical characterisation of $\mathrm{Pt} / \mathrm{Nb}-\mathrm{SnO}_{2}$ loose- tubes}

The nanofibre morphology was analysed by FE-SEM using a Hitachi S-4800 scanning electron microscope. Powder X-ray diffraction (XRD) patterns were recorded at room temperature in Bragg-Brentano configuration using a PANAlytical X'pert diffractometer, equipped with a hybrid monochromator, operating with $\mathrm{CuK}_{\alpha}$ radiation $(\lambda=1.541 \AA)$, and using a step size of $0.1^{\circ} 2 \theta$ within the $2 \theta$ domain from 30 to $55^{\circ}$.

$\mathrm{Pt} / \mathrm{Nb}-\mathrm{SnO}_{2}$ was analysed by $\mathrm{X}$-ray fluorescence, in order to determine the Pt amount effectively on the support. The samples were prepared by grinding $50 \mathrm{mg}$ of $\mathrm{Pt} / \mathrm{Nb}-\mathrm{SnO}_{2}$ with $25 \mathrm{mg}$ of cellulose. The recovered powder was then placed in a cavity in the $\mathrm{H}_{3} \mathrm{BO}_{3}$ matrix subsequently pressed, in order to obtain a pellet of $32 \mathrm{~mm}$ diameter with scanned surface of ca. $12 \mathrm{~mm}$.
The same protocol was utilized to prepare four standards using 15, 20, 25 and $30 \%$ wt of Pt black (Alfa Aesar) and $\mathrm{Nb}-\mathrm{SnO}_{2}$ to obtain a calibration line. The analyses were performed with a PANalytical Axios Max spectrometer fitted with a Rh (4 kW) tube, and equipped with a LiF200 crystal and Omnian software.

\section{Ex situ electrochemical characterisation of $\mathrm{Pt} / \mathrm{Nb}-\mathrm{SnO}_{2}$ loose-tubes}

The ex situ electrochemical analyses were carried out in a conventional three-electrode cell consisting of a glassy carbon rotating disk electrode (RDE) (working electrode, geometric area of $0.196 \mathrm{~cm}^{2}$ ), a reversible hydrogen electrode (reference electrode, RHE) and a platinum wire (counter electrode). A Pine bipotentiostat model AFCBP1 was used. All the potential values are referred to the RHE and the current densities are reported as current per geometric electrode area.

In order to prepare the catalyst ink, $5 \mathrm{mg}$ of the $\mathrm{Pt} / \mathrm{Nb}-\mathrm{SnO}_{2}$ electrocatalyst were dispersed in $10 \mu \mathrm{L}$ milli-Q water, $0.20 \mathrm{~mL}$ of ethanol (Aldrich) and $10 \mu \mathrm{L} 5 \%$ wt $\mathrm{Nafion}^{\circledR}$ solution in alcohols (Aldrich). For the reference, $5 \mathrm{mg}$ of $50 \mathrm{wt} \% \mathrm{Pt} / \mathrm{C}$ (Alfa Aesar) were mixed with $25 \mu \mathrm{L}$ of milli-Q water, $0.35 \mathrm{~mL}$ of ethanol (Aldrich) and $25 \mu \mathrm{L}$ of the $5 \%$ wt Nafion ${ }^{\circledR}$ solution in alcohols (Aldrich). The catalyst inks were sonicated (VWR Ultrasonic Cleaner) for $15 \mathrm{~min}$. Aliquots of $3.8 \mu \mathrm{L}$ of the $\mathrm{Pt} / \mathrm{C}$ ink or $5 \mu \mathrm{L}$ of the $\mathrm{Pt} / \mathrm{Nb}-\mathrm{SnO}_{2}$ ink were then deposited onto the RDE surface with a micropipette and dried in air. The Pt loading was $121.7 \mu \mathrm{g} \mathrm{cm}^{-2}$ for $\mathrm{Pt} / \mathrm{Nb}-\mathrm{SnO}_{2}$ and $121.2 \mu \mathrm{g} \mathrm{cm}^{-2} \mathrm{Pt} / \mathrm{C}$. Cyclic voltammetry was performed in $\mathrm{N}_{2}$ saturated $0.1 \mathrm{M} \mathrm{HClO}_{4}$. For durability experiments 2000 cycles were performed between $0.05 \mathrm{~V}$ and $1.2 \mathrm{~V}$ with a scan rate of $50 \mathrm{mV} \mathrm{s}^{-1}$. The ECSA was evaluated before and after cycling. Its calculation was based on hydrogen adsorption peaks in the range $0.05 \mathrm{~V}$ to $0.4 \mathrm{~V}$ vs RHE after double-layer correction, assuming a monolayer hydrogen adsorption charge of $210 \mu \mathrm{C} \mathrm{cm}^{-2}$ for the Pt surface.

A diluted ink was used for the investigation of the catalytic activity towards the ORR and led to Pt loadings of $14.2 \mu \mathrm{g} \mathrm{cm}^{-2}$ for $\mathrm{Pt} / \mathrm{Nb}-\mathrm{SnO}_{2}$ and $10.5 \mu \mathrm{g} \mathrm{cm}^{-2}$ for $\mathrm{Pt} / \mathrm{C}$. The ORR polarisation curves were recorded using linear sweep voltammetry at 1600 $\mathrm{rpm}$ in $\mathrm{O}_{2}$ saturated $0.1 \mathrm{M} \mathrm{HClO}_{4}$. The potential was varied from 1.0 to $0.2 \mathrm{~V}$ vs RHE at a scan rate of $5 \mathrm{mV} \mathrm{s}^{-1}$. The total current was first corrected for the background current measured in the $\mathrm{N}_{2}$-saturated corresponding electrolyte and then for diffusion limiting using the Koutecky-Levich equation.

\section{Preparation of $\mathrm{Pt} / \mathrm{Nb}-\mathrm{SnO}_{2}$ based MEA and in situ electrochemical characterisation}


GDEs for the anode were purchased from Alfa Aesar. Pt loading was $0.4 \mathrm{mg} \mathrm{cm}^{-2}$. Nafion ${ }^{\circledR} 212$ membranes (Ion Power) were treated before assembly with the electrodes using the following procedure. They were immersed in a $3 \% \mathrm{v} / \mathrm{v} \mathrm{H}_{2} \mathrm{O}_{2}$ solution (30 $\%$ wt., Carlo Erba Reagents), which was stirred for $1 \mathrm{~h}$ at 100 ${ }^{\circ} \mathrm{C}$. After washing with water, the membranes were immersed in a $50 \%$ w/w solution of $\mathrm{HNO}_{3}$ (65\% wt., Sigma Aldrich) and stirred for 30 minutes at room temperature. Finally, the membranes were washed, immersed in a $1 \mathrm{M}$ solution of $\mathrm{H}_{2} \mathrm{SO}_{4}$ (95 wt.\%, Sigma Aldrich) for $1 \mathrm{~h}$ at $100{ }^{\circ} \mathrm{C}$ and rinsed again with water.

The $\mathrm{Pt} / \mathrm{Nb}-\mathrm{SnO}_{2}$ and $\mathrm{Pt} / \mathrm{C}$ based cathode loaded with $0.5 \mathrm{mg} \mathrm{cm}^{-}$

2 of Pt was prepared with the following method. A mixture of $9.5 \mathrm{mg}$ of $\mathrm{Pt} / \mathrm{Nb}-\mathrm{SnO}_{2}$ or $4 \mathrm{mg} \mathrm{Pt} / \mathrm{C}$ catalyst (Alfa Aesar), $46 \mu \mathrm{L}$ of a $5 \%$ wt. Nafion ${ }^{\circledR}$ solution (Sigma-Aldrich), $400 \mu \mathrm{L}$ of water and $2 \mathrm{~mL}$ of ethanol was sonicated for at least $30 \mathrm{~min}$ and sprayed-coated on a GDL ( $4 \mathrm{~cm}^{2}$, Sigracet $\left.10 \mathrm{BC}\right)$.

The MEA was assembled by pressing the electrodes and membrane at $140{ }^{\circ} \mathrm{C}$ for $2 \mathrm{~min}$ at $25 \mathrm{MPa}$. The MEA was then incorporated in the fuel cell setup using fluorinated ethylene propylene (FEP) gaskets at $10-15 \%$ compression. The MEA conditioning step was performed at $0.5 \mathrm{~A} \mathrm{~cm}^{-2}$ overnight at 100 $\% \mathrm{RH}$ and $80{ }^{\circ} \mathrm{C}$. Polarization curves were recorded under $\mathrm{H}_{2} / \mathrm{O}_{2}$ (stoichiometry $1.5 / 2$ ) by setting the current density and measuring the cell potential. A back-pressure of 1 bar was applied (2 bar absolute pressure).

An accelerated stress test (AST), applied in the fuel cell at $80^{\circ} \mathrm{C}$, consisted of a square-wave type voltage cycle, holding at $0.9 \mathrm{~V}$ for $3 \mathrm{sec}$ and at $1.4 \mathrm{~V}$ for $3 \mathrm{sec}$, and repeating 1200 times $^{31}$. Impedance spectroscopy measurements in the range $20 \mathrm{kHz}$ to $100 \mathrm{mHz}$ were performed at $0.1 \mathrm{~A} \mathrm{~cm}^{-2}$ to measure the resistance in the MEA before and after the voltage cycling. BSE-SEM analysis of the MEA sections was performed after the AST.

\section{Results and discussion}

\section{Structure and morphology of $\mathrm{Pt} / \mathrm{Nb}-\mathrm{SnO}_{2}$ loose-tubes}

The morphology of the electrospun $\mathrm{Nb}-\mathrm{SnO}_{2}$ before and after loading with Pt was characterised by scanning and transmission microscopies. The micrograph in Figure 1 a clearly indicates the fibre-in-tube or "loose-tube" structure of the support with an average diameter of ca. $300 \mathrm{~nm}$. As depicted in the images in Figure $1 \mathrm{~b}-\mathrm{c}, \mathrm{Pt}$ nanoparticles with an average diameter of $3 \mathrm{~nm}$ are homogeneously dispersed on the inner and outer surface of the tubes.

From X-ray fluorescence measurements, the Pt loading on $\mathrm{Nb}$ $\mathrm{SnO}_{2}$ was determined as being $21 \%$ wt. The structural analysis of $\mathrm{Pt}$ supported on $\mathrm{Nb}-\mathrm{SnO}_{2}$ loose-tubes is shown in Figure 2. As already evidenced by previous XRD and Raman analyses ${ }^{30}, \mathrm{Nb}-$ $\mathrm{SnO}_{2}$ loose-tubes adopt the tetragonal $\mathrm{P} 42 / \mathrm{mnm}$ cassiterite structure (JCPDS 41-1445). The two broad peaks corresponding to $\mathrm{Pt}(111)$ and $\mathrm{Pt}(200)$ at 40.0 and $46.2^{\circ} 2$ theta, respectively, indicate the small size of the Pt particles. Indeed, the Pt crystallite size calculated from the XRD pattern in Figure 2 using the
Scherrer equation is $4 \mathrm{~nm}$, in good agreement with the TEM observations.

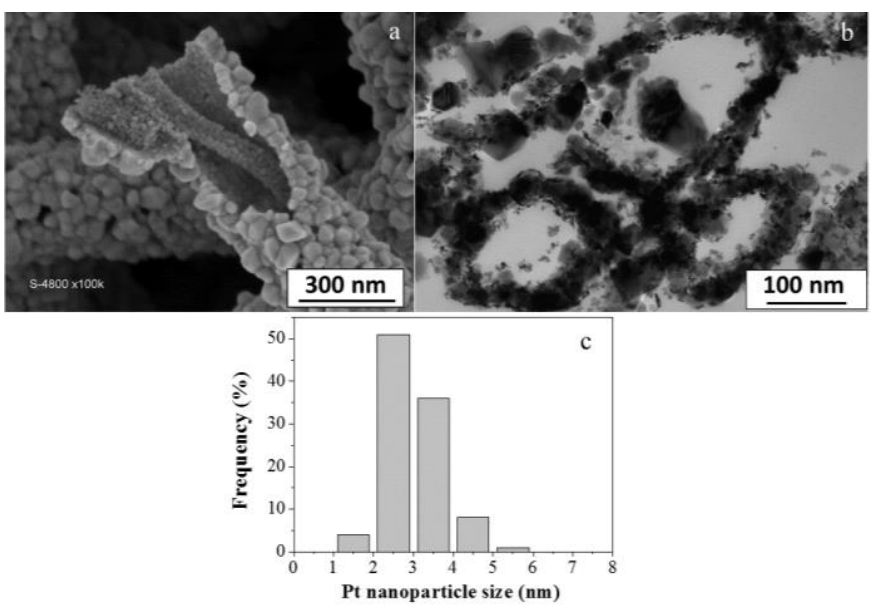

Figure 1. FE-SEM micrographs of bare $\mathrm{Nb}$ doped $\mathrm{SnO}_{2}$ loose-tubes (a) and TEM micrograph of a microtomed section of a Pt catalysed support (b). Pt nanoparticle size distribution histogram (c).

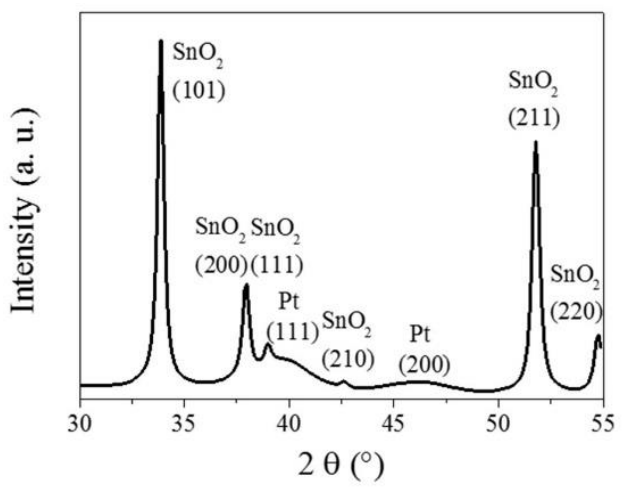

Figure 2. XRD pattern of $\mathrm{Pt}$ supported on $\mathrm{Nb}$ doped $\mathrm{SnO}_{2}$ loose-tubes.

\section{Ex situ electrochemical characterisation}

Cyclic voltammetry (CV) measurements were performed in acidic medium on $\mathrm{Pt} / \mathrm{Nb}-\mathrm{SnO}_{2}$ and for comparison on commercial $\mathrm{Pt} / \mathrm{C}$. The voltammograms in Figure 3 present the characteristic hydrogen adsorption/desorption peaks in the low potential region and $\mathrm{Pt}$ oxide formation and reduction in the high potential region. The Pt electrochemical surface area (ECSA) was calculated from the hydrogen adsorption peak, and had a value of $27 \mathrm{~m}^{2} \mathrm{~g}^{-1}$ for $\mathrm{Pt} / \mathrm{Nb}-\mathrm{SnO}_{2}$. Tsukatsune et al. ${ }^{32}$ reported a similar surface area of $21.4 \mathrm{~m}^{2} \mathrm{~g}^{-1}$ for $20 \% \mathrm{Pt} / \mathrm{Sn}_{0.98} \mathrm{Nb}_{0.02} \mathrm{O}_{2}$. The ECSA values decreased as a consequence of cycling between 0.05 and $1.2 \mathrm{~V}$ vs RHE, as indicated by a decrease in the integrated area of the $\mathrm{H}$ adsorption peaks (Figure 3 ).

The surface area loss over time was stronger for the carbon-based electrode than for the tin oxide based one. Indeed, the ECSA of $\mathrm{Pt} / \mathrm{C}$ decreased much faster with potential cycling than with $\mathrm{Pt} / \mathrm{Nb}-\mathrm{SnO}_{2}$. After 2000 cycles, the former retained only $12 \%$ of its electroactive area, while the latter retained $76 \%$ (Table 1). 

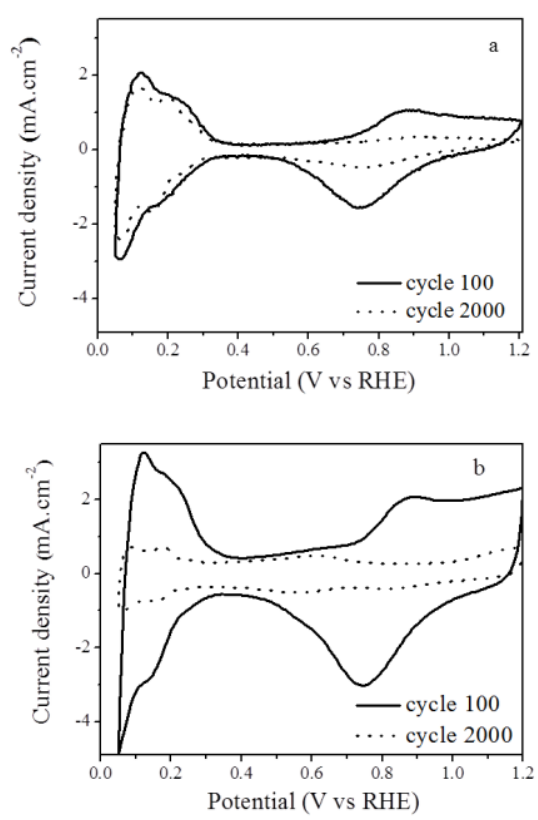

Figure 3 Cyclic voltammograms in $\mathrm{N}_{2}$ purged $0.1 \mathrm{M} \mathrm{HClO}_{4}$ of $21 \% \mathrm{Pt} / \mathrm{NbSnO}_{2}$ (a) and $50 \% \mathrm{Pt} / \mathrm{C}(\mathrm{b})$ before and after voltage cycling.

Table 1. ECSA loss upon cycling for $\mathrm{Pt} / \mathrm{Nb}-\mathrm{SnO}_{2}$ and $\mathrm{Pt} / \mathrm{C}$.

\begin{tabular}{|c|c|c|}
\hline $\mathbf{E C S A}, \mathbf{~ m}^{\mathbf{2}} \mathbf{g}^{-1}$ & $\mathbf{2 1} \boldsymbol{\%} \mathbf{P t} / \mathbf{N b}-\mathbf{S n O}_{\mathbf{2}}$ & $\mathbf{5 0} \% \mathbf{P t} / \mathbf{C}$ \\
\hline Cycle 20 & 27 & 33 \\
\hline Cycle 2000 & 21 & 4 \\
\hline
\end{tabular}

These results can be explained in terms of the corrosion of the carbon support during the prolonged potential cycling. The Pt particles underwent growth, dissolution, migration/agglomeration or detachment from the corroded support, leading to the loss of electroactive area ${ }^{33,34}$. On the other hand, Pt supported on the oxide loose-tubes showed a significantly higher stability to cycling to high voltage. This result is attributed to the corrosion resistance of the support ${ }^{30}$ as well as to strong $\mathrm{Pt}-\mathrm{SnO}_{2}$ interactions, evidence for which has been provided in recent reports on tin oxide based PEMFC cathodes $^{9,31}$.

Furthermore, the anodic current due to the formation of platinum oxides and the cathodic current due to their reduction were observed to decrease, consistent with studies $^{35}$ that have attributed this behaviour to the interaction between $\mathrm{Pt}$ and $\mathrm{SnO}_{2}$, which becomes stronger as the Pt particle density decreased. The activity of $\mathrm{Pt} / \mathrm{Nb}-\mathrm{SnO}_{2}$ towards oxygen reduction was also evaluated and compared to that obtained with conventional $\mathrm{Pt} / \mathrm{C}$. For both electrodes the onset potential of the polarisation curves was around $0.96 \mathrm{~V}$. The ORR mass activities at $0.9 \mathrm{~V}$ were 34 and $87 \mathrm{~A} \mathrm{~g}^{-1} \mathrm{Pt}$ for $21 \% \mathrm{Pt} / \mathrm{Nb}-\mathrm{SnO}_{2}$ and $50 \% \mathrm{Pt} / \mathrm{C}$, respectively. The value concerning the oxide supported $\mathrm{Pt}$ is in agreement with recent results obtained with $\mathrm{Pt}$ deposited onto $\mathrm{Sb}$ doped $\mathrm{SnO}_{2}$ (e.g. $15.5 \mathrm{~A} \mathrm{~g}^{-1} \mathrm{Pt}$ at $0.9 \mathrm{~V}^{16}$ and $94 \mathrm{~A} \mathrm{~g}^{-1} \mathrm{Pt}$ at $0.85 \mathrm{~V}^{20}$ ).
Tafel slopes have been calculated in the kinetically controlled range (Figure 4). For the $\mathrm{Pt} / \mathrm{C}$ electrocatalyst the slope of $-68 \mathrm{mV}$ $\mathrm{dec}^{-1}$ is typical of platinum at low overpotentials ${ }^{36,37}$. A different slope of $-103 \mathrm{mV} \mathrm{dec}{ }^{-1}$ has been obtained for $\mathrm{Pt} / \mathrm{Nb}-\mathrm{SnO}_{2}$, as already reported for $\mathrm{Pt}$ nanoparticles supported on $\mathrm{SnO}_{2}{ }^{8}$. It is known that on polycrystalline $\mathrm{Pt}$ in acidic media in low current density range, a theoretical Tafel slope of $-60 \mathrm{mV} \mathrm{dec}^{-1}$ is obtained, corresponding to the ORR proceeding on oxidecovered $\mathrm{Pt}$, while at high current densities, Tafel slope rises to $120 \mathrm{mV} \mathrm{dec}{ }^{-1}$, indicating a reaction occurring at an oxide-free surface with a transfer coefficient $\alpha$ of $0.5^{38}$. The high value obtained with the tin oxide support, typical of the reduced metal surface, could arise from the capability of $\mathrm{SnO}_{2}$ of adsorbing oxygen species ${ }^{39}$, thus partially reducing the Pt surface even at high potentials.

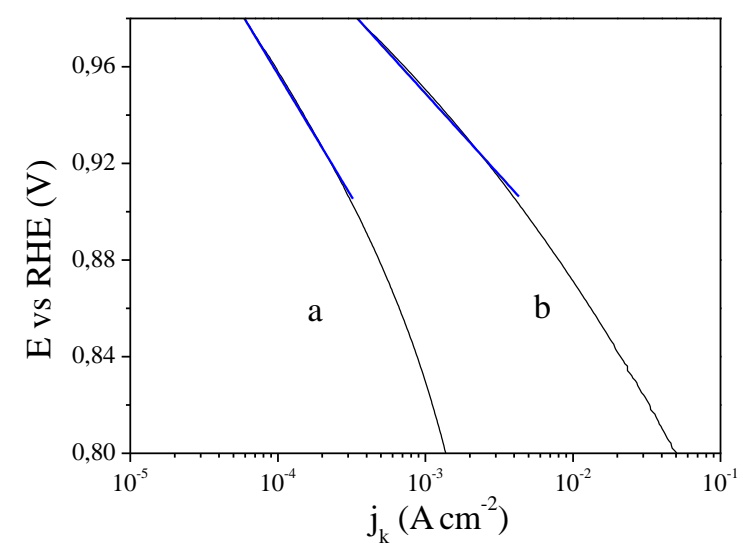

Figure 4. Tafel plots for the oxygen reduction reaction at $21 \% \mathrm{Pt} / \mathrm{Nb}-\mathrm{SnO}_{2}$ (a) and $50 \% \mathrm{Pt} / \mathrm{C}$ (b). In blue, linear extrapolation for Tafel slope determination.

\section{In situ electrochemical characterisation}

Figure 5 shows the current density - voltage curves of the two MEAs with the $\mathrm{Pt} / \mathrm{Nb}-\mathrm{SnO}_{2}$ catalyst and with the commercial $\mathrm{Pt} / \mathrm{C}$ catalysts recorded on $\mathrm{H}_{2} / \mathrm{O}_{2}$ before and after in situ voltage cycling to $1.4 \mathrm{~V}$ (1200 cycles). The initial open circuit voltage (OCV), $0.960 \mathrm{~V}$ for the MEA with the $\mathrm{Pt} / \mathrm{Nb}-\mathrm{SnO}_{2}$ cathode, and $0.962 \mathrm{~V}$ for the reference MEA ( $\mathrm{Pt} / \mathrm{C}$ cathode), is practically unchanged after the accelerated stress test. The IV curves of Figure 5 show that the MEA with the $\mathrm{Pt} / \mathrm{Nb}-\mathrm{SnO}_{2}$ electrode provides lower current density at a given cell voltage (Figure 5 a) than the reference MEA with a Pt/C cathode (Figure $5 \mathrm{~b}$ ), the former displaying a maximum power density of $0.41 \mathrm{~W} . \mathrm{cm}^{-2}$ at a current density of $1 \mathrm{~A} \mathrm{~cm}^{-2}$ compared to $0.96 \mathrm{~W} . \mathrm{cm}^{-2}$ for $\mathrm{Pt} / \mathrm{C}$. This result is probably a consequence of the relatively lower electron conductivity of the oxide compared to the carbon support ${ }^{40}$. The high initial voltage drop at low current density for the $\mathrm{Pt} / \mathrm{NbSnO}_{2}$ based MEA may be assigned to lower ORR activity compared to that of $\mathrm{Pt} / \mathrm{C}$ electrocatalyst ${ }^{8,41}$ as described above for the ex situ analysis.

One of the most important observations of this work concerns the stability of the non-carbon cathode to voltage cycling, when the performance of $\mathrm{Pt} / \mathrm{Nb}-\mathrm{SnO}_{2}$-based MEA was observed to 
slightly increase from 0.41 to $0.47 \mathrm{~W} \mathrm{~cm}^{-2}$ at $1 \mathrm{~A} \mathrm{~cm}^{-2}$ after 600 cycles (Figure 5) ${ }^{41}$ while, in contrast, for the Pt/C-based MEA a dramatic drop in performance was observed.
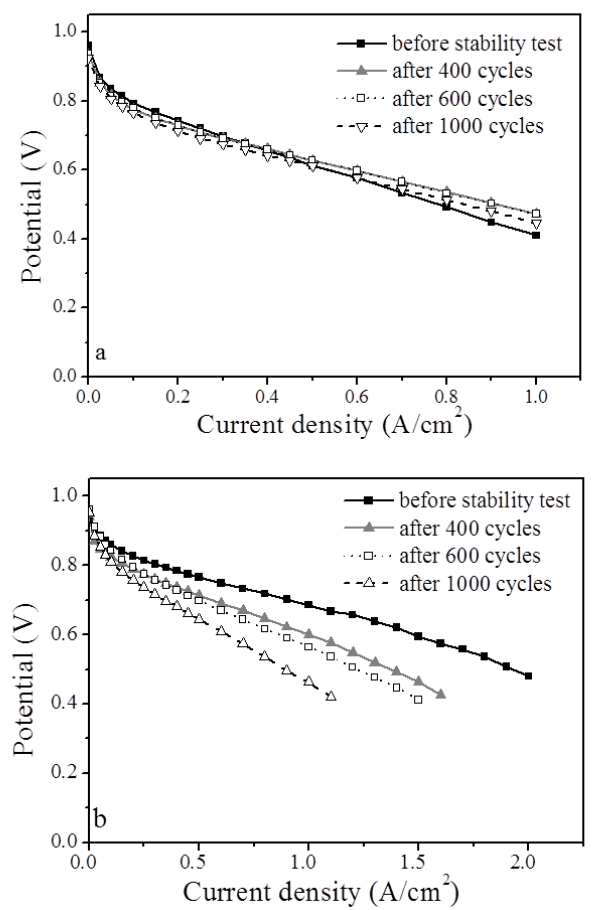

Figure 5. I-V characteristics of MEA with $\mathrm{Pt} / \mathrm{Nb}-\mathrm{SnO}_{2}(\mathrm{a})$ and $\mathrm{Pt} / \mathrm{C}$ (b) before and after in situ voltage cycling.

There was a significant change in both the ohmic and the mass transfer regions, whereas the initial potential drop remains relatively unchanged. This indicates that the loss of performance for the reference MEA ( $\mathrm{Pt} / \mathrm{C}$ cathode) is likely due to deterioration in the conductivity of the catalyst supports and in the mass-transport behaviour of the cathode. Carbon corrosion leads to functionalization of the carbon surface ${ }^{42}$, which results in an increase in the hydrophilicity of the catalyst layer and high mass-transport overpotentials. The fuel cell performance loss is also related to a thinning of the catalyst layer due to detachment and migration of $\mathrm{Pt}$ nanoparticles as a result of carbon corrosion as well as Pt dissolution and migration (see SEM observations after AST). The higher stability of the tin oxide based electrocatalyst at high potentials is explained by their greater corrosion resistance, already demonstrated ex $s i t u^{30}$, which allows retention of morphology and conductivity.

\section{SEM observations after AST}

The morphology of the MEAs after 1200 voltage cycles to $1.4 \mathrm{~V}$ was investigated using electron microscopy. Figure 6 shows a typical BSE-FESEM micrograph of the cross-section of $\mathrm{Pt} / \mathrm{Nb}$ $\mathrm{SnO}_{2}$ and $\mathrm{Pt} / \mathrm{C}$ electrocatalyst layers. In Figure 6 a and c Ptdecorated $\mathrm{Nb}-\mathrm{SnO}_{2}$ tubes are observed with no collapse of the loose-tube structure after either the MEA fabrication that had comprised sonication and spraying of the catalyst ink, and hotpressing, or following voltage cycling. In contrast, the $\mathrm{Pt} / \mathrm{C}$ electrodes of Figure $6 \mathrm{~b}$ and $\mathrm{d}$ show that the nanocatalysts have undergone significant aggregation. Furthermore, thinning of the catalyst layer can be observed due to the detachment and migration of the Pt nanoparticles.

To provide further evidence for the higher stability of the tin oxide based electrode, FE-SEM was performed on the whole MEA cross-section. This allowed observation of the membrane and the eventual formation of a "Pt band" as reported in previous studies of degradation of PEMFC at high cathode potentials ${ }^{43}$. In Figure 7 bright features due to platinum may be observed, that are present not only in the electrodes but also as a band at the mid-point of the MEA. This Pt band is particularly evident in the $\mathrm{Pt} / \mathrm{C}$ based MEA (Figure 7b), which is caused by platinum dissolution from the cathode, migration through the membrane and precipitation as nanoparticles, forming a bright front at the point at where hydrogen and oxygen gas pressures are equilibrated. In the case of $\mathrm{Pt} / \mathrm{Nb}-\mathrm{SnO}_{2}$, this effect is much reduced, being mitigated (Figure 7 a) by the higher corrosion resistance of the support as well as to the strong interaction between $\mathrm{Pt}$ and $\mathrm{SnO}_{2}{ }^{44}$.
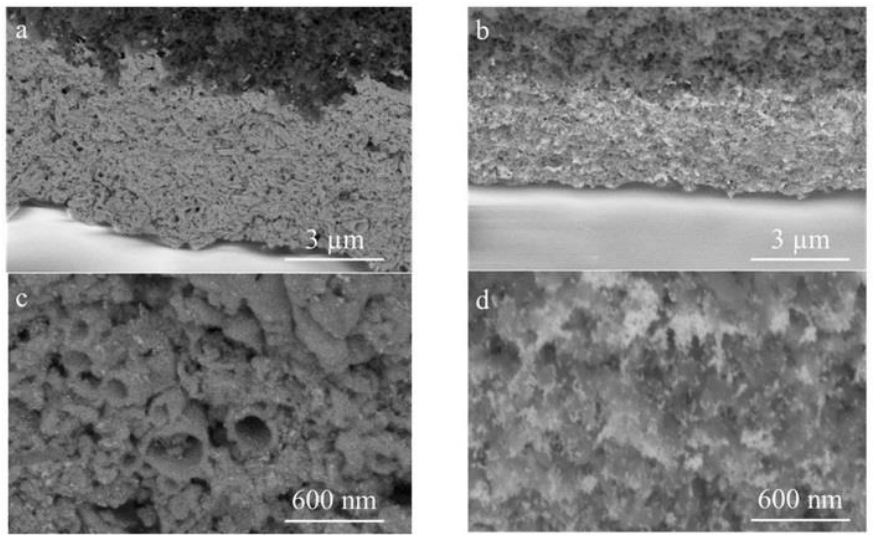

Figure 6. SEM micrographs (BSE mode) of cathodes with $\mathrm{Pt} / \mathrm{NbSnO}_{2}(\mathrm{a}, \mathrm{c}$ ) and $\mathrm{Pt} / \mathrm{C}$ (b, d) after 1200 cycles 0.9-1.4 V.

\section{Impedance spectroscopy}

In order to evaluate the charge transport properties of the $\mathrm{Nb}$ doped $\mathrm{SnO}_{2}$ loose-tubes in comparison with the carbon based electrocatalyst in fuel cell electrodes, Nyquist plots were obtained by electrochemical impedance spectroscopy before and after the stability test. 
A single impedance arc is observed in the Nyquist plot of Figure 8 , the diameter of which corresponds to the charge transfer $\left(R_{c t}\right)$ of the oxygen reduction reaction due to the fast hydrogen oxidation reaction kinetics. A Randles model is usually used to describe a single semicircle loop, where double-layer capacitance is replaced by a constant phase element (CPE) due to porous structure of the electrode ${ }^{45}$. The $\mathrm{R}_{\mathrm{ct}}$ for the $\mathrm{SnO}_{2}$ based electrode was greater than that for carbon-based cathode, as shown in Table 2. This result corroborates the lower initial fuel cell performance observed earlier. However, the $\mathrm{R}_{\mathrm{ct}}$ of tin oxide based MEA remains almost unchanged after voltage cycling. In contrast, $\mathrm{R}_{\mathrm{ct}}$ of carbon based electrode increased dramatically from 0.503 to $0.900 \Omega \mathrm{cm}^{2}$, clearly identifying the performance loss as arising from degradation effects at the cathode (Figures 6 and 7). The ohmic resistance obtained from the intersection of the semicircle loop with the $x$ axis was higher for the MEA with the $\mathrm{Pt} / \mathrm{Nb}-\mathrm{SnO}_{2}$ cathode than that for the reference MEA (Pt/C cathode), as shown in Table 2, due the lower conductivity of the ceramic support.

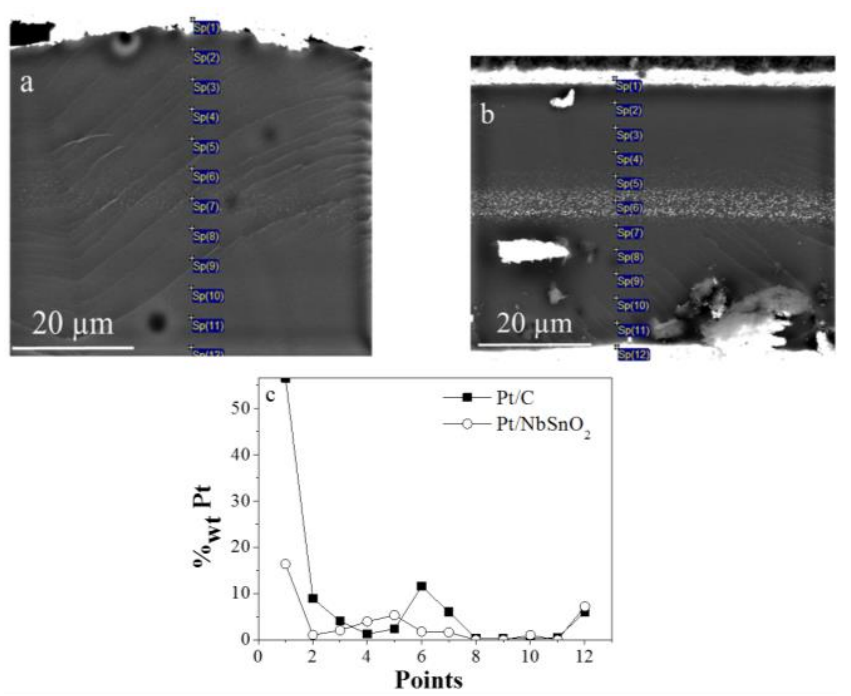

Figure 7. BSE-SEM micrographs of MEAs with $\mathrm{Pt} / \mathrm{Nb}-\mathrm{SnO}_{2}(\mathrm{a})$ and $\mathrm{Pt} / \mathrm{C}(\mathrm{b})$ after 1200 cycles ADT and graphic of the Pt amount as a function of the position (c).

Table 2. Ohmic and charge transfer resistance before and after AST at $0.1 \mathrm{~A} \mathrm{~cm}^{-2}$ for $\mathrm{Pt} / \mathrm{Nb}-\mathrm{SnO}_{2}$ and $\mathrm{Pt} / \mathrm{C}$ cathode based MEAs.

\begin{tabular}{|c|c|c|}
\hline $\begin{array}{c}\text { Number of } \\
\text { cycles }\end{array}$ & $\begin{array}{c}\mathbf{R}_{\text {ohm }}, \mathbf{\Omega} \mathbf{~ c m}^{2} \\
\text { Ohmic resistance }\end{array}$ & $\begin{array}{c}\mathbf{R}_{\text {ct }}, \mathbf{\Omega} \mathbf{~ c m}^{\mathbf{2}} \\
\text { Charge-transfer } \\
\text { resistance }\end{array}$ \\
\hline \multicolumn{3}{|c|}{$\boldsymbol{P t / C}$} \\
\hline$O$ & 0.071 & 0.503 \\
\hline 1200 & 0.070 & 0.900 \\
\hline \multicolumn{3}{|c|}{$\boldsymbol{P t / N b S n O _ { 2 }}$} \\
\hline$O$ & 0.095 & 0.835 \\
\hline 1200 & 0.098 & 0.810 \\
\hline
\end{tabular}
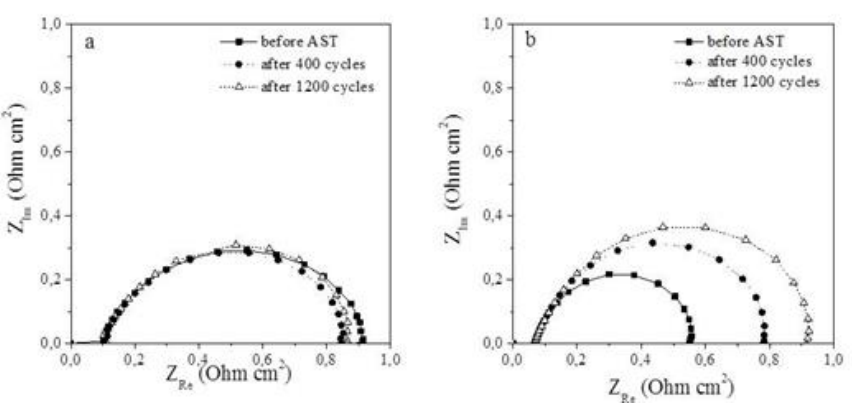

Figure 8. Nyquist plots of $\mathrm{Pt} / \mathrm{Nb}-\mathrm{SnO}_{2}(\mathrm{a})$ and $\mathrm{Pt} / \mathrm{C}(\mathrm{b})$ before and after voltage cycling test.

\section{Conclusions}

$\mathrm{Nb}$-doped $\mathrm{SnO}_{2}$ loose-tubes loaded with $\mathrm{Pt}$ nanoparticles demonstrated higher electrochemical stability than conventional $\mathrm{Pt} / \mathrm{C}$ electrodes under prolonged potential cycling with good performance in the oxygen reduction reaction. Fuel cell tests confirmed the enhanced durability over time of the cathodes prepared with the alternative supports. Electron microscopy analyses performed after the in situ accelerated stress tests confirmed that the $1 \mathrm{D}$ morphology was retained. Furthermore, due to the strong metal support interaction, the Pt nanoparticles did not agglomerate or detach from $\mathrm{Nb}-\mathrm{SnO}_{2}$, whereas in the carbon based cathode Pt was lost from the support and formed a band in the membrane. These results show the clear promise of associating doped tin oxide compositions with electrospinning to tune the support morphology and surface area and with microwave assisted polyol method to rapidly prepare monodisperse electrocatalyst particles, for preparation of cathode catalyst support for PEMFC with designed architecture and tuned corrosion resistance. This work has further highlighted the need for higher support conductivity which will require further modulation of the support composition, and increased electrocatalyst mass activity for which support architecture and porosity are key determining factors.

\section{Acknowledgements}

The research leading to these results has received funding from the Future Emerging Technologies (FET) Programme under the European Community Seventh Framework Programme (FP/2007-2013) under Grant Agreement 256821. The authors gratefully acknowledge this financial support. I.S. acknowledges the financial support from French National Research Agency (ANR-12-PRGE-0007).

Furthermore the research leading to these results has received funding from the European Research Council under the European Union's Seventh Framework Programme (FP/20072013) / ERC Grant Agreement n. 306682. 


\section{Notes and references}

a Institut Charles Gerhardt, UMR CNRS 5253, Agrégats Interfaces Matériaux pour l'Energie, Université de Montpellier - 34095 Montpellier Cedex 5, France

*E-mail: sara.cavaliere @univ-montp2.fr; Fax: +33 (0)4 671433 04; Tel: +33(0)467149098

1. M. Wesselmark, B. Wickman, C. Lagergren and G. Lindbergh, Electrochim. Acta, 2010, 55, 7590-7596.

2. A. Bauer, L. Chevallier, R. Hui, S. Cavaliere, J. Zhang, D. Jones and J. Rozière, Electrochim. Acta, 2012, 77, 1-7.

3. L. Chevallier, A. Bauer, S. Cavaliere, R. Hui, J. Rozière and D. J. Jones, ACS Appl. Mater. Interfaces, 2012, 4, 1752-1759.

4. S. Cavaliere, S. Subianto, L. Chevallier, D. J. Jones and J. Rozière, Chem. Commun. (Camb)., 2011, 47, 6834-6836.

5. H. Chhina, S. Campbell and O. Kesler, J. Electrochem. Soc., 2007, 154, B533.

6. P. J. Kulesza, K. Miecznikowski, B. Baranowska, M. Skunik, a. Kolary-Zurowska, a. Lewera, K. Karnicka, M. Chojak, I. Rutkowska, S. Fiechter, P. Bogdanoff, I. Dorbandt, G. Zehl, R. Hiesgen, E. Dirk, K. S. Nagabhushana and H. Boennemann, $J$. Appl. Electrochem., 2007, 37, 1439-1446.

7. M. S. Saha, M. N. Banis, Y. Zhang, R. Li, X. Sun, M. Cai and F. T. Wagner, J. Power Sources, 2009, 192, 330-335.

8. P. Zhang, S.-Y. Huang and B. N. Popov, J. Electrochem. Soc., 2010, 157, B1163.

9. F. Takasaki, S. Matsuie, Y. Takabatake, Z. Noda, a. Hayashi, Y. Shiratori, K. Ito and K. Sasaki, J. Electrochem. Soc., 2011, 158, B1270.

10. A. Ignaszak, C. Teo, S. Ye and G. Elod, J. Phys. Chem. C, 2010, 114, 16488-16504.

11. M. Sudan Saha, R. Li, M. Cai and X. Sun, Electrochem. Solid-State Lett., 2007, 10, B130.

12. V. Tripković, I. Cerri, T. Nagami, T. Bligaard and J. Rossmeisl, Phys. Chem. Chem. Phys., 2013, 15, 3279-85.

13. Y. Shao, J. Liu, Y. Wang and Y. Lin, J. Mater. Chem., 2009, 19, 46-59.

14. M. Fehse, S. Cavaliere, P. E. Lippens, I. Savych, a. Iadecola, L. Monconduit, D. J. Jones, J. Rozière, F. Fischer, C. Tessier and L. Stievano, J. Phys. Chem. C, 2013, 117, 13827-13835.

15. Y. Wang, T. Brezesinski, M. Antonietti and B. Smarsly, ACS Nano, 2009, 3, 1373-1378.

16. E. Fabbri, a Rabis, R. Kötz and T. J. Schmidt, Phys. Chem. Chem. Phys., 2014, 16, 13672-81.
17. M. Yin, J. Xu, Q. Li, J. O. Jensen, Y. Huang, L. N. Cleemann, N. J. Bjerrum and W. Xing, Appl. Catal. B Environ., 2014, 144, 112120 .

18. Y. Senoo, K. Taniguchi, K. Kakinuma, M. Uchida, H. Uchida, S. Deki and M. Watanabe, Electrochem. commun., 2015, 51, 37-40.

19. D. J. You, K. Kwon, C. Pak and H. Chang, Catal. Today, 2009, 146, 15-19.

$20 . \quad$ N. R. Elezovic, B. M. Babic, V. R. Radmilovic and N. V. Krstajic, J. Electrochem. Soc., 2013, 160, F1151-F1158.

21. M. S. Saha, V. Neburchilov, D. Ghosh and J. Zhang, Wiley Interdiscip. Rev. Energy Environ., 2013, 2, 31-51.

S. Cavaliere, S. Subianto, I. Savych, D. J. Jones and J. Rozière, Energy Environ. Sci., 2011, 4, 4761-4785.

A. Bauer, K. Lee, C. Song, Y. Xie, J. Zhang and R. Hui, J. Power Sources, 2010, 195, 3105-3110.

Q. Long, M. Cai, J. Li, H. Rong and L. Jiang, J. Nanoparticle Res., 2010, 13, 1655-1662.

25

L. Yang, M. Vukmirovic, D. Su, K. Sasaki, J. Herron, M. Mavrikakis, S. Liao and R. R. Adzic, J. Phys. Chem. C, 2013, 117, 1748-1753.

K. Senevirathne, R. Hui, S. Campbell, S. Ye and J. Zhang, Electrochim. Acta, 2012, 59, 538-547.

27. I. Savych, J. Bernard d'Arbigny, S. Subianto, S. Cavaliere, D. J. Jones and J. Rozière, J. Power Sources, 2014, 257, 147-155.

28. A. B. Suryamas, G. M. Anilkumar, S. Sago, T. Ogi and K. Okuyama, Catal. Commun., 2013, 33, 11-14.

S. Sago, A. B. Suryamas, G. M. Anilkumar, T. Ogi and K. Okuyama, Mater. Lett., 2013, 105, 202-205.

S. Cavaliere, S. Subianto, I. Savych, M. Tillard, D. J. Jones, J. Rozière and D. J. Jones, J. Phys. Chem. C, 2013, 117, 18298 18307.

31. K. Kakinuma, Y. Chino, Y. Senoo, M. Uchida, T. Kamino, H. Uchida, S. Deki and M. Watanabe, Electrochim. Acta, 2013, 110, 316-324.

T. Tsukatsune, Y. Takabatake and Z. Noda, ECS Trans., 2013, 58, $1251-1257$.

33. Y. Shao, G. Yin and Y. Gao, J. Power Sources, 2007, 171, 558 566.

34. Y. Sugawara, A. P. Yadav, A. Nishikata and T. Tsuru, $J$. Electroanal. Chem., 2011, 662, 379-383.

35. M. Nakada, A. Ishihara, S. Mitsushima, N. Kamiya and K. Ota, Electrochem. Solid-State Lett., 2007, 10, F1. 

Catalyst Layers. Fundamentals and Applications, ed. J. Zhang, Springer-Verlag, 2008, pp. 89-134.

37. N. Wakabayashi, M. Takeichi, M. Itagaki, H. Uchida and M. Watanabe, J. Electroanal. Chem., 2005, 574, 339-346.

38. D. A. Walsh, A. Ejigu, J. Smith and P. Licence, Phys. Chem. Chem. Phys., 2013, 15, 7548-54.

39. S. Mukerjee and J. McBreen, J. Electrochem. Soc., 1999, 146, 600606.

40. K. Kanda, Z. Noda, Y. Nagamatsu, T. Higashi, S. Taniguchi, S. M. Lyth, a. Hayashi and K. Sasaki, ECS Electrochem. Lett., 2014, 3, F15-F18.

41. T. Higashi, ECS Trans., 2013, 58, 1293-1299.

42. Y. Yang and Z. G. Lin, J. Appl. Electrochem., 1995, 25, 259-266.

43. J. Peron, Y. Nedellec, D. Jones and J. Rozière, J. Power Sources, 2008, 185, 1209-1217.

44. S. J. Tauster, Acc. Chem. Res., 1987, 20, 389-394.

45. X. Yuan, H. Wang, J. Colinsun and J. Zhang, Int. J. Hydrogen Energy, 2007, 32, 4365-4380. 